\title{
Engaging tourism students through multi-media teaching and active learning
}

\author{
By Christian Schott and Kathryn Sutherland
}

This is an Accepted Manuscript of an article published by Taylor \& Francis in the Journal of Teaching in Travel \& Tourism on 21/08/2009, available online doi:

$10.1080 / 15313220903047987$ 
ENGAGING TOURISM STUDENTS THROUGH MULTI-MEDIA TEACHING AND ACTIVE

\section{LEARNING}

Authors: Christian Schott and Kathryn Sutherland

Abstract

Teachers of tourism play an important role in assisting students to develop geographical knowledge and a sound understanding of tourism terminology and statistics, coupled with an ability to put these attributes into use in appropriate, creative, and competent ways. This article describes a multi-media based teaching technique used in a New Zealand university tourism course and presents research findings regarding its impacts. In particular, the technique motivated students to attend and participate in class, and contributed to a reported increase in tourism-related knowledge, as well as understanding of and appreciation for other cultures.

Keywords: Student engagement, active learning, tourism community, multi-media teaching

\section{Contact Information}

Dr Christian Schott

Senior Lecturer, Victoria Management School

Victoria University of Wellington

PO Box 600, Wellington, 6140

New Zealand

Christian.Schott@vuw.ac.nz

Dr Kathryn Sutherland

Senior Lecturer, University Teaching Development Centre

Victoria University of Wellington

PO Box 600, Wellington, 6140

New Zealand

Kathryn.Sutherland@vuw.ac.nz 


\section{INTRODUCTION}

Tourism, as an academic discipline as well as an economic sector, values graduates with geographical knowledge, a sound understanding of key global geo-political dynamics, knowledge of tourism terminology and statistics, and an ability to put these attributes into use in appropriate, creative, and competent ways. Such graduates possess the "shared repertoire" (language, artefacts, and actions) that help to define a community (Wenger, 1998). Tourism education and teachers of tourism, specifically, play an important role in assisting students to acquire these skills and knowledge and in encouraging a sense of inclusion in the tourism community. In an attempt to show possible ways for cultivating this shared repertoire, this article describes a multi-media based teaching technique used in a New Zealand university tourism course and presents research findings regarding its impacts. The technique is designed to provide pathways for students to develop an increased understanding of tourism specific terminology and key statistics, as well as related geographical and geo-political knowledge and skills, through student engagement and active learning. It is also designed to appeal to twenty first century students who live in a fast-paced, digital world where multi-media use is common, and increasingly expected in university classrooms.

The article begins with a short review of the literature on active learning and the use of multi-media in teaching. Subsequently, each aspect of the technique is explained in detail and accompanied by a rationale that draws on pertinent literature in the area. Research findings examining the technique's impact and effectiveness are then presented and discussed. The aim of the paper is to provide other university teachers with a description of a teaching technique that encourages student engagement 
and develops understanding. We believe that the technique will be adaptable into a variety of disciplines, including tourism, geography, management, business, indeed any discipline with a global and/or sustainable outlook.

\section{Background}

TOUR250, Managing Visitor Impacts, is a second year course, compulsory for Bachelor of Tourism Management students at Victoria University of Wellington in Aotearoa New Zealand. Enrolling 4070 students each year, it comprises 24 hours of lectures, 10 hours of tutorials and a day-long field trip. The course focuses on the concept of sustainable tourism development as the overarching theoretical framework for both examining and managing the impacts of visitors. Given the nature and philosophical underpinnings of this material, the lecturer seeks to 'walk the talk' in applying some of the central value components embedded in the concept of sustainability to the course and his teaching. These include building an understanding of interrelationships and comprehensive (rather than 'tumnel-vision') knowledge, broadening geographical and geo-political knowledge to aid in building a deeper understanding of the sources of some of the challenges the world faces in the $21^{\text {st }}$ century, and fostering an improved understanding of different countries' cultures and key characteristics to illustrate the diverse nature of tourism, its stakeholders and impacts worldwide.

The teaching technique was developed and modified over a period of five years, and is used as an opening format for every TOUR250 lecture. Briefly, the technique consists of music playing when students enter the class, an informal verbal quiz about the country represented by the music, a factsheet on the country's key tourism statistics, a virtual visit to the country using web-based 
mapping software Google Earth, and a virtual visit to one of the country's key tourist attractions also using Google Earth.

\section{Active learning and student engagement}

Active learning is a popular education catchphrase - and arguably a "movement" (Mattson, 2005) with roots in Bruner's (1961) discovery learning, John Dewey's (1938) pragmatic "learning by doing", and inquiry-based learning. Bluntly put, active learning "involves students in doing things and thinking about the things they are doing" (Bonwell and Eison, 1991, p. 2) and moves students beyond the role of passive recipients of the lecturer's knowledge.

Research shows that active learning which is deliberately designed, carefully implemented, cognitively focussed and thoughtfully evaluated can improve student interest, motivation and engagement (Hanson \& Moser, 2003; Prince, 2004), enhance student knowledge and understanding of course content (Chickering \& Gamson, 1987; Prince, 2004), increase retention (Braxton, Milem \& Sullivan, 2000), help to develop life long learners (Clegg, 2000, cited in Wolfe, 2006) and improve student perceptions of teaching effectiveness (Scott, 2007).

Prince (2004) in a review of the literature on active learning declares that there is wide support from empirical research "for all forms of active learning" but particularly for active engagement methods: "The best available evidence suggests that faculty should structure their courses to promote collaborative and cooperative environments" (p. 7). Similarly, Mayer (2004), in a review of literature on discovery learning in the US, lauds the growth in teaching that actively engages students, but 
warns that active learning should not be mere behavioural activity. Rather, "the kind of activity that really promotes meaningful learning is cognitive activity (e.g. selecting, organizing, and integrating knowledge)" (Mayer, 2004, p. 17). Furthermore, active learning which engages students' senses as well as their cognitive abilities is likely to have an even bigger impact on learning than cognitive activity alone (Nairn, 1999).

\section{Use of Multimedia}

Active learning through various media in undergraduate classrooms engages many senses, but is also increasingly popular because of the growing demand for twenty first century university graduates to be "digitally literate" in order to thrive in a technologically dominated world (Prensky, 2006). The current generation of students is wired, connected, and mobile: in the United States, nearly all ( $97 \%)$ own computers and cell phones (94\%) (Junco \& Mastrodicasa, 2007). The figures in New Zealand (where our research was conducted) are similar, with Scornavacca and Marshall (2007) reporting that $96.8 \%$ of students own a cell phone.

Echoing Nairn's idea, above, that engaging the senses is crucial to enhancing student learning, Liiu (1997) cited in Chopoorian et al (2001) concludes that if attention and focus are the foundation for learning, then the use of multimedia is a powerful pedagogical tool because it captivates the greatest number of senses and sparks imagination. Several studies have looked at the power of visual images in undergraduate lectures (Keegan, 2007) and of computer technology and internet-based tools (Mitchell, 2007; Fargher, 2006). Zwyno and Waalen (2001) found that attendance rates in lectures were much higher in multimedia-enhanced lectures than in the conventional class. In tourism, particularly, Keegan (2007) conducted a study on the importance of visual images in Tourism 
Management second year lectures and found that images made the lecture more interesting and increased the concentration level among students. Images "also helped them remember concepts, so serving as a trigger to a topic" (p. 61). And, Wolfe (2006) in a short article on active learning in tourism and hospitality education settings cites several possibilities for the active use of multimedia, such as reservations systems, systems learning projects, "Jeopardy" type games and personal response systems (p. 76).

However, a lecturer's use of multimedia is not an automatic guarantee that students will learn anything, let alone learn more effectively. Chopoorian et al (2001) argue strongly that computer technology can support good teaching, but cannot substitute for good teachers. In addition, such instruction is more effective (1) when it requires students to be active participants rather than passive learners and (2) when two or more channels (images, motion, sound, text, etc) are used in the presentation (p. 85).

\section{Overview of the technique}

Introduced and administered like a virtual tour around the world originating and returning to New Zealand the technique provides a brief case-study of a different country at the beginning of each lecture. During the first two years of the technique's evolution the lecturer simply played music from a different country at the beginning of each lecture and supported the music with a quiz and key geographical and population information about the country. Additional media, such as Google Earth and the factsheet, were added over the last few years to enhance students' motivation and ability to interact with the respective country. On average the technique lasts five to ten minutes, depending on 
the level of engagement the lecturer wishes students to establish with the country, which in turn is dependent on the week's lecture and tutorial content.

The next section explains how the technique is applied to the lecture setting, elaborates on the motivation for selecting each component and medium, and examines the intended benefits of intertwining the components and media to create a comprehensive teaching engagement technique.

\section{Component 1: Popular music from the country}

Five to ten minutes prior to the scheduled start of the lecture, the lecturer plays music over the lecture theatre's audio system. The music is carefully selected to ensure a strong association with a particular country, for example Bossa Nova in the case of Brazil, Calypso for Barbados, Sithar-based music for India, Bouzouki-based music for Greece and so on. When the students enter the lecture theatre they experience an environment filled with 'world' music; the music is only turned down when the lecture begins. With music playing quietly in the background, the lecturer welcomes the students to the lecture, and then asks the class to name the music's country of origin. From the beginning of the course, students are strongly encouraged to speculate and 'shout out' a suggestion; if required, the lecturer guides suggestions with hints and geographical directions. Once the correct country has been named, the lecturer broadens the quiz and uses a factsheet prepared for each country to verify the answers. 
Rationale for the use of music

Fargher (2006) argues that "the level of development of geographical thinking about both local and more distant places is strongly affected by the channels through which we present geographical information to [students]" (p. 1). The rationale for playing music in TOUR250 is thus guided by the aim of lessening the perceived spatial and temporal distance between the class and the country and its people. As music conjures up representations of place, identity and culture (Connell and Gibson, 2002), music can provide a vibrant yet easily accessible representation of the selected country's culture.

Lopera (2003) argues that songs can change students' understanding of social contexts, change their moods, and provide stimulation and entertainment as well as challenge and pleasure. An additional motivation for playing music in TOUR250 is that the lecturer found through previous observation that music appears to create a relaxing, non-threatening and indeed social and 'chatty' atmosphere, best described as a café atmosphere.

\section{Component 2: Country-specific quiz}

After the case-study country has been named, students are asked to share their knowledge of the country's basic geographical characteristics. This typically includes naming the capital, the population size, the number of international visitors received, bordering countries, as well as other questions (such as highest mountain, percentage of electricity produced by fossil fuel, etc) depending on the country and focus of the lecture and tutorial content. During this casual quiz, comparisons 
between the country under study and countries previously examined are drawn and incorporated as direction to guide any speculative answers.

\section{Rationale}

The design of the quiz is motivated by four objectives. Firstly, as this informal quiz is not assessed and participation is entirely optional for students, it is intended to create a space at the beginning of each lecture that fosters playful but engaged learning. This interactive learning environment is created to help students retain information about the country which might subsequently be useful in a number of contexts - academic and non-academic. Secondly, it is expected that students will develop a greater sense of confidence and depth of understanding when studying countries and important contextual issues such as climate change and carbon emissions. Thirdly, the quiz allows the lecturer to acknowledge students' existing knowledge and experience; for example $46 \%$ of those enrolled in the course in 2007 were of a nationality other than New Zealand. While this international group was dominated by Asian countries of origin it spanned 10 different nationalities. This mix of nationalities and cultures means that in some cases students are highly knowledgeable about the country under study. As the lecturer has not visited all the countries presented during this 24 lecture course, this creates a reciprocal learning environment as the lecturer (supported by the factsheet described below) shows a willingness to also learn from students' knowledge and experiences. A related benefit is that this quiz allows the class to learn more about the interesting countries and cultures that their classmates originate from. Finally, the relaxed and non-threatening nature of the quiz is also intended to encourage students' active participation in lectures by fostering a culture of discussion and interaction where educated guesses are encouraged and incorrect answers are part of the journey of learning. 
Haigh (2002) claims that "many universities are investigating ways of integrating international and multicultural dimensions into their teaching, research and service functions" motivated by "income" and "the globalisation of business and communication patterns [and] the emergence of a 'new knowledge economy"' (pp. 50-51). But, it is not enough to invite high fee paying international students into our lecture halls without considering how we can best support their learning and how all nationalities can harness the opportunities that an internationalised classroom offers. As Barron (2006) suggests, "western universities and western academics might take a more proactive approach regarding the learning experience of such students" (p. 2). This point is echoed by Haigh (2002) who argues that teaching methods and curricula must become more multi-cultural and inclusive because "flexible styles of student-constructed and student-centred learning leave greater scope for pluralism than conventional instruction" (p.50). The TOUR250 opening format's objective of increasing cultural inclusion also finds strong support with Haigh who argues that the twenty-first century internationalised classroom should include course content that does not advantage 'stay-athome' students, but rather widens the scope of the curriculum, increasing the international range of case studies, and increasing the emphasis given to learning and authorities from other traditions.

\section{Component 3: Factsheet about the country}

After the completion of the quiz the lecturer distributes the country factsheet to all students with the advice that none of the material in the factsheet will be assessed and that they are under no obligation to take a copy; it is merely intended for those interested in the material.

The factsheet consists of one two-sided piece of paper, with information for each country researched 
and compiled from the latest Central Intelligence Agency's World Factbook and United Nations World Tourism Organisation's (UNWTO) Country Data. The following sections are addressed in every factsheet:

- Map of country

- Brief historical overview

- Geographical information

- Population information

- Economic information

- Energy source information

- Tourism inbound statistics (including expenditure)

- Tourism outbound statistics (including expenditure)

- Scale of country's hospitality industry

- Tourism industry's contribution to country's economy

\section{Rationale}

Once student curiosity about the country has been raised by the music and the quiz, the factsheet provides readily accessible and easily filed information in a comprehensive format. The factsheet is designed to deepen students' knowledge about a country, expose them to language in which to engage in the discourse of the Tourism disciplinary community, and encourage them to apply this language and knowledge to the course, to other university courses, and to everyday life.

McKinney (2004) in a study on successful learning in sociology, found that students repeatedly talked about the need to make connections between class and text, the abstract and the concrete, the 
material and their lives, the teachers' style and their own, and between the teacher's work and their own work. McKinney's study found that connections involving relevance and application were seen as very important. This finds strong application in the TOUR250 technique where connections are established between the country and the music, the terminology and the discipline, the students and the teacher, and the various nationalities represented in the classroom.

Component 4: A student-assisted virtual visit to the country and a key tourist attraction

During the music and quiz, a virtual globe powered by web-based Google Earth is spinning on the projection screen. The globe adds a visual dimension to the technique, by allowing students to examine the earth's geography while it slowly spins in the background. After distribution of the factsheet, student participation is sought to locate the country on the virtual globe. The class has the option of providing directions to the lecturer 'travelling' around the globe by use of his mouse, or of coming to the front of the room to use the mouse themselves. Once the country has been located, the lecturer initially 'zooms in' to display more geographical detail of the country before embarking on a brief virtual visit to a key tourist attraction. Google Earth's features enable the lecturer to display detailed geographical features, landscape topography, high resolution panoramic photos, and a small selection of three-dimensional models of buildings and monuments. In the case of Greece, for example, the lecturer guides the class on a virtual visit to the Acropolis in the heart of Athens, where the topographical and three-dimensional features are used to enhance the detail of the virtual visit. 


\section{Rationale}

TOUR250 uses Google Earth to encourage digital literacy in its students and to enhance the intensity and effectiveness of their knowledge about the country, through both graphical and applied media.

The virtual visit allows students to examine visual images and models of a tourist site and to understand the relative size and location of these sites. This improved knowledge of the earth's geography is intended to help increase students' confidence and ability to understand and contextualise global tourism examples frequently used in this and other tourism courses. This virtual visit also enables the lecturer to illustrate the diverse capabilities of this web-based mapping software. As Google Earth can be downloaded by anyone free of charge from the Internet, students can use it in their own time to explore the earth, copy user-defined maps, improve their understanding of geographically-based discussions, complete assignments, or simply cater to their curiosity about our diverse planet.

A comprehensive US report by Green (2007) found that the use of digital images in teaching achieves a plethora of outcomes including students' increased engagement with class content, a focus on the skills needed to read and interpret images, students working more with images directly, teachers having more freedom to be creative in producing more lively and interactive classes, and a general improvement in teachers' overall effectiveness. These findings clearly support our rationale for the incorporation of maps and photographic images, while Google Earth enhances these qualities further by providing a context and minimising the risk of distorted or inappropriate projections of geographical information. 
Mitchell (2007) found that "Google Earth type viewers contribute to many pupils' understanding of the inter connection of places, including to a sense of their place in the world" (p. 4). He lauds the capabilities of internet-based tools (such as Google Earth) for giving students the ability to make geographical connections, think geographically and even experience simultaneity rather than "a static contemporaneity in thinking of space" (p.5); at the heart of which is a sense of communication between different places and people in both space and time. Google Earth then clearly enhances the possibility of connection - spatially, visually, geographically - for TOUR250 students. However, the immediacy of Google Earth with its pseudo-live footage risks students thinking they are witnessing and part of an "instantaneous world, a two-dimensional, horizontal world without the depth of a complex history of development over time" (Mitchell, 2007, p. 2). In TOUR250, this risk is mitigated by the use of music and the factsheets, which instead encourage a holistic view of the country, its culture/s and its people.

\section{Research aim}

The aim of the research described below was to gain an understanding of students' views and responses to the use of the teaching technique as described above. For this purpose an in-class selfcomplete questionnaire was selected as the most appropriate technique. (Copies of the questionnaire are available by contacting the authors.)

\section{Research methodology}

After conducting a pilot questionnaire in 2006, a review of the questionnaire and findings led to adjustments being made to the questionnaire used in 2007 and 2008. The questions removed or 
adjusted after the pilot asked about music in other courses (deemed unnecessary to ask in this research), and emotional responses to music (there were too many options provided in the pilot, which students found confusing). Thus, the final questionnaire comprised 20 questions (reduced from 23 in the pilot) which asked about students' perceptions of the opening format of TOUR250, their use and awareness of various media (music and Google Earth, for example) in and outside class, and demographic information. The questions sought responses on a Likert scale where ' 1 ' indicated strong agreement and ' 5 ' indicated strong disagreement. In some cases the Likert scale was 4-point and focused on frequency, where ' 1 ' represented "Always" and '4' represented "Never". In both years the survey was conducted at the beginning of a pre-selected lecture towards the end of the course. To ensure confidentiality of student responses the lecturer left the room and the co-author (who works in the teaching and learning centre and is unknown to the students) administered the survey. Students received an information sheet advising that participation was voluntary and anonymous, that their participation would have no impact on their assessment in the course, and that the questionnaire would take approximately 10 minutes to complete.

On the day the 2007 survey was administered, an uncharacteristically small proportion of enrolled students $(57 \%)$ attended the lecture; however, of those 38 that attended 37 participated in the research. The 2008 rate of attendance at the research lecture was $72 \%$, with again just one attending student not participating (31 of the 32 attending students completed the questionnaire.) We acknowledge that the responses are thus not fully representative of all TOUR250 students in 20072008, and the following findings must be examined and understood with this limitation in mind. The findings are displayed and discussed in aggregate format combining the responses for both years because the focus of the research is to gain an insight into how students respond to the technique rather than seeking to explore differences between the 2007 and 2008 cohort. Thus a total of 68 
respondents completed the questionnaire of a total population of 110 students.

\section{Findings and Discussion}

Some variations were detected between the demographics of the students enrolled in the course and survey participants; these variations are notably in the context of ethnicity and gender, particularly male survey participants and New Zealand Maori are under-represented. Apart from these differences the characteristics of the students enrolled are broadly reflected by the respondent group.

\begin{tabular}{|l|r|r|r|r|}
\hline & $\begin{array}{c}\text { Enrolled in } \\
2007 \text { course } \\
(\%)\end{array}$ & $\begin{array}{c}\text { Participated } \\
\text { in 2007 } \\
\text { survey (\%) }\end{array}$ & $\begin{array}{c}\text { Enrolled in } \\
\text { 2008 course } \\
(\%)\end{array}$ & $\begin{array}{c}\text { Participated } \\
\text { in 2008 } \\
\text { survey (\%) }\end{array}$ \\
\hline Ethnicity & & & & 71.0 \\
\hline NZ European/Pakeha & 47.9 & 48.7 & 56.8 & 3.2 \\
\hline NZ Maori & 29.5 & 32.4 & 11.4 & 12.9 \\
\hline Asian ethnicity & 14.0 & 13.5 & 20.4 & 12.9 \\
\hline Other ethnicity & $100(n=66)$ & $100(n=37)$ & $100(n=44)$ & $100(n=31)$ \\
\hline Total & & & & 22.6 \\
\hline Sex & 31.0 & 18.9 & 25.0 & 77.4 \\
\hline Male & 69.0 & 81.1 & 75.0 & $100(n=31)$ \\
\hline Female & $100(n=66)$ & $100(n=37)$ & $100(n=44)$ & \\
\hline Total & & & & 51.6 \\
\hline Age group & 59.5 & 60.6 & 47.7 & 38.7 \\
\hline 20 and under & 29.7 & 29.6 & 43.2 & 9.7 \\
\hline $21-24$ years & 10.8 & 9.8 & 9.1 & $100(n=31)$ \\
\hline 25 and older & $100(n=66)$ & $100(n=37)$ & $100(n=44)$ & \\
\hline Total & & & & \\
\hline
\end{tabular}

Table 1: Respondent characteristics

Impact of music

A series of attitude questions was used to gain an understanding of the range of impacts that the use 
of music has on students. The following findings represent the aggregated "Strongly agree" and "Agree" responses on a 5-point Likert scale. Almost all (97\%) respondents in both years said that music at the beginning of TOUR250 lectures creates a welcoming atmosphere and more than twothirds report that it also relaxes them (Table 2). In the context of the music's intended role to broaden the students' awareness and understanding of other cultures the majority of students felt that this is achieved. It is particularly encouraging that $90 \%$ of respondents reported that the music raised their awareness of other cultures and that $74 \%$ felt that it raised their understanding of other cultures. These findings validate the role of the selected music as a vibrant representation of a country's culture and its effectiveness as a tool to communicate aspects of this culture.

\begin{tabular}{|c|c|c|c|c|c|c|}
\hline $\begin{array}{c}\text { Music at the beginning of } \\
\text { lectures.... }\end{array}$ & Year & $\begin{array}{l}\text { Strongly } \\
\text { agree } \\
(\%)\end{array}$ & $\begin{array}{c}\text { Agree } \\
(\%)\end{array}$ & $\begin{array}{l}\text { Neutral } \\
(\%)\end{array}$ & $\begin{array}{l}\text { Disagree } \\
\text { (\%) }\end{array}$ & $\begin{array}{c}\text { Strongly } \\
\text { disagree } \\
(\%)\end{array}$ \\
\hline \multirow[t]{3}{*}{ a) relaxes me } & $2007(n=37)$ & 45.9 & 27.0 & 24.3 & 2.7 & 0.0 \\
\hline & $2008(n=31)$ & 25.8 & 41.9 & 29.0 & 3.2 & 0.0 \\
\hline & Total $(n=68)$ & 36.8 & 33.8 & 26.5 & 2.9 & 0.0 \\
\hline \multirow{3}{*}{$\begin{array}{l}\text { b) creates a welcoming } \\
\text { atmosphere }\end{array}$} & $2007(n=37)$ & 62.2 & 37.8 & 0.0 & 0.0 & 0.0 \\
\hline & $2008(n=31)$ & 61.3 & 32.3 & 6.5 & 0.0 & 0.0 \\
\hline & Total $(n=68)$ & 61.8 & 35.3 & 2.9 & 0.0 & 0.0 \\
\hline \multirow{3}{*}{$\begin{array}{l}\text { c) has raised my } \\
\text { awareness of music from } \\
\text { other countries }\end{array}$} & $2007(n=37)$ & 48.6 & 48.6 & 2.7 & 0.0 & 0.0 \\
\hline & $2008(n=31)$ & 48.4 & 41.9 & 6.5 & 3.2 & 0.0 \\
\hline & Total $(n=68)$ & 48.5 & 45.6 & $\overline{4.4}$ & 1.5 & 0.0 \\
\hline \multirow{3}{*}{$\begin{array}{l}\text { d) has raised my } \\
\text { awareness of other } \\
\text { cultures }\end{array}$} & $2007(n=37)$ & 45.9 & 45.9 & 8.1 & 0.0 & 0.0 \\
\hline & $2008(n=31)$ & 25.8 & 61.3 & 9.7 & 3.2 & 0.0 \\
\hline & Total $(n=68)$ & 36.8 & 52.9 & 8.8 & 1.5 & 0.0 \\
\hline \multirow{3}{*}{$\begin{array}{l}\text { e) has raised my } \\
\text { understanding of other } \\
\text { cultures }\end{array}$} & $2007(n=37)$ & 35.1 & 45.9 & 18.1 & 0.0 & 0.0 \\
\hline & $2008(n=31)$ & 12.9 & 51.6 & 32.3 & 3.2 & 0.0 \\
\hline & Total $(n=68)$ & 25.0 & 48.5 & 25.0 & 1.5 & 0.0 \\
\hline
\end{tabular}

Table 2. Responses to music in class 
Impact of quiz

Given that the authors consider the quiz an important pedagogical component in creating an active learning environment, it was gratifying to discover that $95 \%$ respondents enjoyed the lecturer asking the class to name the music's country of origin, as well as asking questions about the country represented by the music. Table 3 illustrates that not all students participated in the music quiz, however, interestingly students are much more likely to discuss an answer with people sitting near them ( $77 \%$ always or often do this) than provide an answer to the lecturer (only $27 \%$ give an answer that the whole class can hear). While similar dynamics are found with respect to asking students questions about the country, the key finding is that the majority of students actively engage with the questions, be it in the context of the whole class or in discussion with students sitting near them. This validates the notion that even in interactive contexts students learn and benefit from scenarios and in settings that are not always observable by the lecturer.

\begin{tabular}{|c|c|c|c|c|c|}
\hline $\begin{array}{l}\text { When asked to name the music's } \\
\text { country of origin }\end{array}$ & Year & $\begin{array}{c}\text { Always } \\
(\%)\end{array}$ & $\begin{array}{c}\text { Often } \\
(\%)\end{array}$ & $\begin{array}{c}\text { Rarely } \\
(\%)\end{array}$ & $\begin{array}{c}\text { Never } \\
(\%)\end{array}$ \\
\hline \multirow{3}{*}{$\begin{array}{l}\text { I provide an answer that the whole } \\
\text { class can hear }\end{array}$} & $2007(n=37)$ & 5.4 & 16.2 & 54.1 & 24.3 \\
\hline & $2008(n=31)$ & 3.2 & 29.0 & 41.9 & 25.8 \\
\hline & Total $(n=68)$ & 4.4 & 22.1 & 48.5 & 25.0 \\
\hline \multirow{3}{*}{$\begin{array}{l}\text { I give a quiet answer/suggestion to } \\
\text { people sitting near me }\end{array}$} & $2007(n=37)$ & 16.2 & 59.5 & 21.6 & 2.7 \\
\hline & $2008(n=31)$ & 38.7 & 38.7 & 6.5 & 16.1 \\
\hline & Total $(n=68)$ & 26.5 & 50.0 & 14.7 & 8.8 \\
\hline $\begin{array}{l}\text { When asked about the country } \\
\text { represented by the music }\end{array}$ & Year & $\begin{array}{c}\text { Always } \\
(\%)\end{array}$ & $\begin{array}{c}\text { Often } \\
(\%)\end{array}$ & $\begin{array}{c}\text { Rarely } \\
(\%)\end{array}$ & $\begin{array}{c}\text { Never } \\
(\%)\end{array}$ \\
\hline \multirow{3}{*}{$\begin{array}{l}\text { Iprovide answers that the whole class } \\
\text { can hear }\end{array}$} & $2007(n=37)$ & 2.7 & 13.5 & 56.8 & 27.0 \\
\hline & $2008(n=31)$ & 0.0 & 22.6 & 48.4 & 29.0 \\
\hline & Total $(n=68)$ & 1.5 & 17.6 & 52.9 & 27.9 \\
\hline \multirow{3}{*}{$\begin{array}{l}\text { I give a quiet answer/suggestion to } \\
\text { people sitting near me }\end{array}$} & $2007(n=37)$ & 10.8 & 59.5 & 27.0 & 2.7 \\
\hline & $2008(n=31)$ & 22.6 & 48.4 & 12.9 & 16.1 \\
\hline & Total $(n=68)$ & 16.2 & 54.4 & 20.6 & 8.8 \\
\hline
\end{tabular}

Table 3: Respondents' actions when asked questions during in-class quiz 


\section{Impact of factsheet}

Despite it being optional for students to take a copy of the factsheet, $91 \%$ report that they always do. The greatest level of interest in the information provided is recorded with regard to tourism, followed by background, population and geographical information (Table 4); not surprisingly these are the areas of greatest relevance to the content of the course. The fact that more than half of the respondents consistently read these four sections of information arguably shows that the factsheet helps them develop an interest in and increase their knowledge about the country.

\begin{tabular}{|c|c|c|c|c|}
\hline Factsheet Related Behaviour & Year & Always (\%) & Sometimes (\%) & Never (\%) \\
\hline \multirow{3}{*}{$\begin{array}{l}\text { take copy of the factsheet when } \\
\text { circulated }\end{array}$} & $2007(n=37)$ & 97.3 & 2.7 & 0.0 \\
\hline & $2008(n=31)$ & 83.9 & 12.9 & 3.2 \\
\hline & Total $(n=68)$ & 91.2 & 7.4 & 1.5 \\
\hline \multirow{3}{*}{$\begin{array}{l}\text { read background (history) } \\
\text { information }\end{array}$} & $2007(n=37)$ & 59.5 & 40.5 & 0.0 \\
\hline & $2008(n=27)$ & 37.0 & 55.6 & 7.4 \\
\hline & Total $(n=64)$ & 50.0 & 46.9 & 3.1 \\
\hline \multirow[t]{3}{*}{ read geographical information } & $2007(n=37)$ & 51.4 & 43.2 & 5.4 \\
\hline & $2008(n=27)$ & 19.2 & 57.7 & 23.1 \\
\hline & Total $(n=64)$ & 38.1 & 49.2 & 12.7 \\
\hline \multirow[t]{3}{*}{ read population information } & $2007(n=36)$ & 54.1 & 43.2 & 0.0 \\
\hline & $2008(n=27)$ & 29.6 & 63.0 & 7.4 \\
\hline & Total $(n=63)$ & 44.4 & 52.4 & 3.2 \\
\hline \multirow[t]{3}{*}{ read economic information } & $2007(n=36)$ & 27.8 & 66.7 & 5.6 \\
\hline & $2008(n=27)$ & 14.8 & 66.7 & 18.5 \\
\hline & Total $(n=63)$ & 27.0 & 60.3 & 12.7 \\
\hline \multirow[t]{3}{*}{ read energy information } & $2007(n=36)$ & 27.8 & 66.7 & 5.6 \\
\hline & $2008(n=27)$ & 15.4 & 57.7 & 26.9 \\
\hline & Total $(n=63)$ & 22.6 & 62.9 & 14.5 \\
\hline \multirow[t]{3}{*}{ read tourism information } & $2007(n=37)$ & 81.1 & 18.9 & 0.0 \\
\hline & $2008(n=27)$ & 48.1 & 51.9 & 0.0 \\
\hline & Total $(n=64)$ & 67.2 & 32.8 & 0.0 \\
\hline Impact factsheet had on.... & Year & $\begin{array}{c}\text { Increased my } \\
\text { understanding } \\
(\%)\end{array}$ & $\begin{array}{l}\text { Didn't change } \\
\text { it (\%) }\end{array}$ & $\begin{array}{l}\text { Confused my } \\
\text { understanding } \\
(\%)\end{array}$ \\
\hline \multirow{2}{*}{$\begin{array}{l}\text { a) understanding of key terminology } \\
\text { frequently used in tourism? }\end{array}$} & $2007(n=36)$ & 41.7 & 58.3 & 0.0 \\
\hline & $2008(n=28)$ & 28.6 & 71.4 & 0.0 \\
\hline
\end{tabular}




\begin{tabular}{|l|c|c|c|c|}
\hline & Total $(\mathrm{n}=64)$ & 35.9 & 64.1 & 0.0 \\
\hline $\begin{array}{l}\text { b) ability to understand other tourism } \\
\text { lectures and/or courses? }\end{array}$ & $2007(\mathrm{n}=37)$ & 43.2 & 56.8 & 0.0 \\
\cline { 2 - 5 } & $2008(\mathrm{n}=26)$ & 34.6 & 65.4 & 0.0 \\
\cline { 2 - 5 } & Total $(\mathrm{n}=63)$ & 39.7 & 60.3 & 0.0 \\
\hline
\end{tabular}

Table 4: Respondent Use of and Response to the Factsheet

However the most important finding in assessing the factsheet's value is that $36 \%$ of respondents report that it increased their understanding of key tourism terminology, and $40 \%$ said that it increased their ability to understand the content of other tourism lectures and courses (Table 4). Given that any increase in students' reported level of understanding is a desirable outcome, these percentages demonstrate that the technique is meeting its objectives.

\section{Impact of Google Earth}

Of the respondents who had not encountered Google Earth before, nearly half downloaded a copy onto their personal computer. And over half of the respondents report that they have used Google Earth for something other than personal interest since encountering it in the course (Table 5).

\begin{tabular}{|c|c|c|c|}
\hline Use of Google Earth ... & Year & Yes (\%) & No $(\%)$ \\
\hline \multirow{3}{*}{$\begin{array}{l}\text { a) come across Google Earth before it } \\
\text { was first used in } 250\end{array}$} & $2007(n=37)$ & 64.9 & 35.1 \\
\hline & $2008(n=31)$ & 77.4 & 22.6 \\
\hline & Total $(n=68)$ & 70.6 & 29.4 \\
\hline \multirow{3}{*}{$\begin{array}{l}\text { b) If no, since seeing it in } 250 \text { have you } \\
\text { downloaded a copy onto your personal } \\
\text { computer? }\end{array}$} & $2007(n=14)$ & 50.0 & 50.0 \\
\hline & $2008(n=8)$ & 25.0 & 75.0 \\
\hline & Total $(n=22)$ & 40.9 & 59.1 \\
\hline \multirow{3}{*}{$\begin{array}{l}\text { c) Since seeing Google Earth in this } \\
\text { course have you used it for any } \\
\text { purpose other than personal interest? }\end{array}$} & $2007(n=37)$ & 56.7 & 43.3 \\
\hline & $2008(n=30)$ & 46.7 & 53.3 \\
\hline & Total $(n=67)$ & 52.2 & $\mathbf{4 7 . 8}$ \\
\hline
\end{tabular}

Table 5: Use of Google Earth by Respondents 
The overwhelming majority (94\%) of respondents report that their understanding of world geography and tourist destinations has increased since seeing Google Earth in TOUR250 (Table 6). These results indicate that Google Earth has a very positive impact on geographically and tourism driven student learning outcomes; the fact that students can use the software to interactively explore the earth in their own time and under their own control is likely to aid in this process and as such is a very valuable extension of the course's learning strategy.

\begin{tabular}{|l|l|l|l|l|l|}
\hline $\begin{array}{c}\text { Impact of use of Google } \\
\text { Earth on .... }\end{array}$ & Year & $\begin{array}{c}\text { Greatly } \\
\text { increased it } \\
(\%)\end{array}$ & $\begin{array}{c}\text { Increased it } \\
(\%)\end{array}$ & $\begin{array}{c}\text { It remained } \\
\text { the same (\%) }\end{array}$ & $\begin{array}{c}\text { Confused it } \\
(\%)\end{array}$ \\
\hline \multirow{2}{*}{$\begin{array}{c}\text { a) understanding of } \\
\text { geography of the world }\end{array}$} & $2007(n=37)$ & 37.8 & 59.5 & 2.7 & 0.0 \\
\cline { 2 - 6 } & $2008(n=31)$ & 29.0 & 61.3 & 9.7 & 0.0 \\
\cline { 2 - 6 } & Total $(n=68)$ & 33.8 & 60.3 & 5.9 & 0.0 \\
\hline \multirow{2}{*}{$\begin{array}{c}\text { b) understanding of tourist } \\
\text { destinations around the } \\
\text { world }\end{array}$} & $2007(n=37)$ & 40.5 & 51.4 & 8.1 & 0.0 \\
\cline { 2 - 6 } & $2008(n=31)$ & 29.0 & 67.7 & 3.2 & 0.0 \\
\cline { 2 - 6 } & Total $(n=68)$ & 35.3 & 58.8 & 5.9 & 0.0 \\
\hline
\end{tabular}

Table 6: Impact of use of Google Earth on 2007 Respondents

\section{Discussion}

The motivational impact of the teaching technique in its entirety can be regarded as very encouraging as consistently half of the respondents state that the technique has increased their level of motivation (Table 7); motivation to attend lectures (56\%); motivation to actively participate in lectures (49\%); and, motivation to stay focused during lectures $(53 \%)$.

\begin{tabular}{|l|c|c|c|c|}
\hline $\begin{array}{l}\text { How has the opening format } \\
\text { of TouR250 lectures } \\
\text { influenced.... }\end{array}$ & Year & $\begin{array}{c}\text { Increased } \\
(\%)\end{array}$ & $\begin{array}{c}\text { Stayed the same } \\
(\%)\end{array}$ & $\begin{array}{c}\text { Decreased } \\
(\%)\end{array}$ \\
\hline $\begin{array}{l}\text { a) your motivation to attend } 250 \\
\text { lectures }\end{array}$ & $2007(n=37)$ & 62.2 & 37.8 & 0.0 \\
\cline { 2 - 5 } & $2008(n=31)$ & 48.4 & 51.6 & 0.0 \\
\cline { 2 - 5 } & Total $(n=68)$ & 55.9 & 44.1 & 0.0 \\
\hline b) your motivation to actively & $2007(n=37)$ & 51.4 & 48.6 & 0.0 \\
\hline
\end{tabular}




\begin{tabular}{|l|l|l|l|l|}
\hline \multirow{4}{*}{ participate in 250 lectures } & $2008(n=31)$ & 45.2 & 51.6 & 3.2 \\
\cline { 2 - 5 } & Total $(n=68)$ & 48.5 & 50.0 & 1.5 \\
\hline \multirow{3}{*}{\begin{tabular}{l} 
c) your motivation to stay $\begin{array}{l}\text { focused during TOUR250 } \\
\text { lectures }\end{array}$ \\
\cline { 2 - 5 }
\end{tabular}} & $2007(n=37)$ & 62.2 & 37.8 & 0.0 \\
\cline { 2 - 5 } & $2008(n=31)$ & 41.9 & 54.8 & 3.2 \\
\cline { 2 - 5 } & Total $(n=68)$ & 52.9 & 45.6 & 1.5 \\
\hline
\end{tabular}

Table 7: Impact of opening format on respondent motivation

Finally, the overall impact of the technique as a comprehensive and integrated teaching tool is illustrated by Table 8 to be highly effective in achieving its objectives. Specifically, $94 \%$ of respondents strongly agree or agree that the technique creates a welcoming atmosphere. However more importantly, $57 \%$ are in agreement that it helps them understand the content of TOUR250 lectures better, while nearly half (43\%) strongly agree or agree that it helps them better understand the content of other tourism courses. The students ultimately provide an overall endorsement of the technique with nine in ten responding students strongly agreeing or agreeing that it should remain an integral part of the course when it is next taught.

\begin{tabular}{|c|c|c|c|c|c|c|}
\hline $\begin{array}{c}\text { The opening format of } \\
\text { TOUR250 }\end{array}$ & Year & $\begin{array}{l}\text { Strongly } \\
\text { agree } \\
(\%)\end{array}$ & $\begin{array}{c}\text { Agree } \\
(\%)\end{array}$ & $\begin{array}{l}\text { Neutral } \\
(\%)\end{array}$ & $\begin{array}{c}\text { Disagree } \\
(\%)\end{array}$ & $\begin{array}{l}\text { Strongly } \\
\text { disagree } \\
(\%)\end{array}$ \\
\hline \multirow{3}{*}{$\begin{array}{l}\text { a) creates a welcoming } \\
\text { atmosphere }\end{array}$} & $2007(n=37)$ & 59.5 & 37.8 & 2.7 & 0.0 & 0.0 \\
\hline & $2008(n=31)$ & 45.2 & 45.2 & 9.7 & 0.0 & 0.0 \\
\hline & Total $(n=68)$ & 52.9 & 41.2 & 5.9 & 0.0 & 0.0 \\
\hline \multirow{3}{*}{$\begin{array}{l}\text { b) helps me understand the } \\
\text { content of } 250 \text { lectures } \\
\text { better }\end{array}$} & $2007(n=37)$ & 29.7 & 32.4 & 37.8 & 0.0 & 0.0 \\
\hline & $2008(n=31)$ & 9.7 & 41.9 & 45.2 & 3.2 & 0.0 \\
\hline & Total $(n=68)$ & 20.6 & 36.8 & 41.2 & 1.5 & 0.0 \\
\hline \multirow{3}{*}{$\begin{array}{l}\text { c) should remain an integral } \\
\text { part of the course the next } \\
\text { time it is offered }\end{array}$} & $2007(n=37)$ & 70.3 & 27.0 & 2.7 & 0.0 & 0.0 \\
\hline & $2008(n=31)$ & 38.7 & 41.9 & 16.1 & 3.2 & 0.0 \\
\hline & Total $(n=68)$ & 55.9 & 33.8 & 8.8 & 1.5 & 0.0 \\
\hline \multirow{3}{*}{$\begin{array}{l}\text { d) should not be used as the } \\
\text { time would be better spent } \\
\text { on content }\end{array}$} & $2007(n=37)$ & 2.7 & 0.0 & 10.8 & 48.6 & 37.8 \\
\hline & $2008(n=31)$ & 0.0 & 9.7 & 25.8 & 35.5 & 29.0 \\
\hline & Total $(n=68)$ & 1.5 & 4.4 & 17.6 & 42.6 & 33.8 \\
\hline \multirow{3}{*}{$\begin{array}{l}\text { e) } 250 \text { helps me understand } \\
\text { the content of other tourism } \\
\text { courses better }\end{array}$} & $2007(n=37)$ & 24.3 & 32.4 & 40.5 & 0.0 & 0.0 \\
\hline & $2008(n=31)$ & 9.7 & 16.1 & 61.3 & 12.9 & 0.0 \\
\hline & Total $(n=68)$ & 17.6 & 25.0 & 50.0 & 7.4 & 0.0 \\
\hline
\end{tabular}

Table 8. General impact of comprehensive technique 
As a final piece of evidence that the opening format of TOUR250 lectures has had a positive impact on students, the formal student evaluations of the course collected at the end of each year, have improved dramatically since the technique was introduced (Table 9). From 2002-2006, the final question asked students to rate the standard of teaching on the course on a scale where $1=$ Outstanding and $5=$ Very poor. The mean in 2002 was 2.1 , but by 2006 , when the opening format had been fully implemented, the mean had improved to 1.6. In 2007, the university-wide student evaluation system changed and the final question was rephrased to ask about the quality of the course overall, including the standard of teaching. The means have remained in the excellent range and in 2008 , the mean was 1.5 . Of course, this improvement cannot be fully attributed to the opening format and many other factors have an influence on this mean, but we are confident that the multimedia technique described in this article has had some positive bearing on these results.

Table 9: Student Opinion of Standard of Teaching and Quality of Course, as Recorded on Formal End-ofCourse Student Evaluation

\begin{tabular}{|c|c|c|c|c|c|c|}
\hline \multicolumn{7}{|c|}{ Standard of teaching in course } \\
\hline Year & Outstanding \% & Good \% & Satisfactory \% & Poor \% & Very poor \% & Mean \\
\hline 2002 & 12 & 69 & 16 & 2 & 0 & 2.1 \\
\hline 2003 & 7 & 65 & 26 & 2 & 0 & 2.2 \\
\hline 2004 & 24 & 62 & 14 & 0 & 0 & 1.9 \\
\hline 2005 & 33 & 57 & 6 & 4 & 0 & 1.7 \\
\hline 2006 & 40 & 51 & 9 & 0 & 0 & 1.6 \\
\hline \multicolumn{7}{|c|}{ Quality of this course } \\
\hline Year & Excellent \% & Very good $\%$ & Good \% & Poor \% & Very poor \% & Mean \\
\hline 2007 & 54 & 32 & 11 & 0 & 0 & 1.5 \\
\hline 2008 & 44 & 44 & 8 & 5 & 0 & 1.5 \\
\hline
\end{tabular}

\section{Conclusion}

The goal of this teaching technique is to encourage students to develop a sound understanding of tourism specific terminology and key statistics, increase their geographical and geo-political knowledge, and to feel a part of the tourism community. Wenger (1998) argues that communities 
are recognisable, in part, by their shared repertoire. Our contention is that the opening format of the TOUR250 lectures demonstrates various aspects of the tourism community's "repertoire": an awareness of geographical, historical, population, economic and energy statistics and information; an ability to understand, manipulate, and use maps; an appreciation for and understanding of other cultures and countries; and a willingness to engage with other members of the community. And, our research has shown that students in TOUR250 are well on their way to developing this shared repertoire, having increased their understanding of information, statistics and cultures; used Google Earth inside and outside of the classroom; deepened their knowledge of and appreciation for other cultures' music; and increased their motivation to actively participate in lectures. We recognise that technology changes rapidly and Google Earth may well be replaced by newer, better, faster technology even by the time this article has been published. However, we hope that our ongoing use of emerging technologies like Google Earth alongside an established medium like music will demonstrate for students the power of various media in learning. Finally, we recognise that this research reports on respondents' perceptions only and does not represent the views of every member of the class, but we take heart from the encouraging results, and look forward to developing this research further. We aim to investigate actual participation in the quiz, through classroom observation, as well as conducting pre- and post-tests on students' knowledge of tourism terminology. This technique will be transferable into numerous other teaching contexts and we encourage readers to implement it in their own lecture halls, and, as we will, to develop it further as media and technologies continue to develop and change. 


\section{REFERENCES}

Barron, P. (2006). Learning issues and learning problems of Confucian heritage culture students studying hospitality and tourism management in Australia. Joumal of Teaching in Travel \& Tourism, 6(4): 1-17. DOI: 10.1300/J172v06n04_01.

Bonwell, C \& Eison, J. (1991). Active learning: Creating excitement in the classroom. San Francisco: Jossey-Bass.

Braxton, J., Millem, J., \& Sullivan, A. (2000). The influence of active learning on the college student departure process: Toward a revision of tinto's theory. Journal of Higher Education 7l(5), 569-590.

Bruner, J. S. (1961). The act of discovery. Harvard Educational Review 31 (1): 21-32.

Chickering, A. \& Gamson, Z. (1987). Seven Principles for Good Practice in Undergraduate Education. http://www.uis.edu/liberalstudies/students/documents/sevenprinciples.pdf. Last accessed 6 May 2008.

Chopoorian, J. Karakaya, F., Ainscough, T. L. (2001). The effects of class size and learning style on student performance in a multimedia-based marketing course. Journal of Marketing Education, 23 (2): 84-90.

Connell, J. \& Gibson, C. (2002). Sound tracks: popular music, identity, and place. London: Routledge.

Dewey, J. (1997). Experience and Education. (1938). New York: Touchstone.

Fargher, M. (2006). Linking lessons learnt from the Spatially Speaking project with research findings on pedagogies with GIS. Downloaded from www.geography.org.uk. Last accessed 04 March 2008.

Green, D. (2007). Using digital images in teaching and learning. A NITLE/Wesleyan University Project. http://hdl.handle.net/10090/2883. Last accessed 04 March 2008. 
Haigh, M. J. (2002). Internationalisation of the curriculum: Designing inclusive education for a small world. Journal of Geography in Higher Education, 26 (1): 49-66.

Hanson, S. \& Moser, S. (2003). Reflections on a discipline-wide project: Developing active learning modules on the human dimensions of global change. Joumal of Geography in Higher Education 27 (1), 17-38.

Junco, R. \& Mastrodicasa, J. (2007). Connecting to the Net.Generation: What Higher Education Professionals Need to Know About Today's Students. Washington, DC: NASPA.

Keegan, S. N. (2007). Importance of Visual Images in Lectures: Case Study on Tourism Management Students. Journal of Hospitality, Leisure, Sport and Tourism Education, 6 (1), 58-65.

Lopera, S. (2003). Useful ideas when taking a song to class. lkala, revista de lenguaje y cultura, 8 (14): 135-149.

McKinney, K. (2004). Leaming sociology: Successful majors tell their story. Journal of Scholarship of Teaching and Learning, $4(1): 15-24$.

Mattson, K. (2005). Why 'active learning' can be perilous to the profession. Academe 91 (1): 23-26.

Mayer, R. E. (2004). Should there be a three-strikes rule against pure discovery learning? American Psychologist, 59 (1): 14-19.

Mitchell, D. (2007). ICT in school Geography - more than motivation. GeogEd. Online journal. http://www.geography.org.uk/projects/gtip/geogede-journal/article2. Last accessed: 1 March 2008.

Naim, K. (1999). Embodied fieldwork. Journal of Geography, 98: 272-82.

Prensky, M. (2006). Listen to the natives. Educational Leadership, 64 (4): 8-13. 
Prince, M. (2004). Does active learning work? A review of the research. Journal of Engineering Education, 93 (3): 223 231.

Scott, N. (2007). An evaluation of the effects of using case method on student leaming outcomes in a tourism strategic planning course. Journal of Teaching in Travel \& Tourism, 7(2): 21-34.

Scomavacca, E. \& Marshall, S.J. (2007) TXT-2-LRN: improving students' learning experience in the classroom through interactive SMS. Proceedings of the 40th Hawaii International Conference on System Sciences. http:/csdl2.computer.org/comp/proceedings/hicss/2007/2755/00/27550005b.pdf. Last accessed 03 March 2008.

Wenger, E. (1998). Communities of practice: Learning, meaning, and identity. Cambridge: CUP.

Wolfe, K. (2006). Active learning. Journal of Teaching in Travel \& Tourism, 6 (1), 77-82. doi:10.1300/J172v06n01_05

Zwyno, M. \& Waalen, J. (2001). Student outcomes and attitudes in technology-enabled and traditional education: a case study. Global Journal of Engineering Education, 5 (1), 49-56. 